\title{
Social Technology Application - Pais- in Association with the Semiarid in the Brazilian Northeast
}

\author{
José Falcão Sobrinho \\ Post-Doctor in Geography. \\ State University of Vale do Acaraú (UVA) \\ Ceará, Brasil \\ Cleire Lima da Costa Falcão \\ PhD in Physical Geography. \\ State University of Ceará (UECE) \\ Ceará, Brasil \\ Maria Raiane of Gomes \\ Techniques in Fruit Growing \\ Federal Institute of Education (IFCE) \\ Ceará, Brasil \\ Vanessa Campos Alves \\ Technical Laboratory \\ State University of Vale do Acaraú (UVA) \\ Ceará, Brasil
}

\begin{abstract}
The study aims to understand the influence of natural and social elements of the living technologies with the semi-arid environment in the communities located in Morgado and Gregório which belong to the Massapê County inserted to the state of Ceara northwest in Brazil and belongs to basin of Acaraú. In this perspective, the focus was directed to the Integrated Agroecology and Sustainable production technology - PAIS, developed by the community residents. The study agenda is based on the approach of the General Systems Theory proposed by Bertalanffy in 1930. Dedicated to the Theory, considering the nature, economy and local sustainability, which are three elements prevalent in the context of the observed landscapes in the Study areas. It is noted that in the communities the influence of semiaridity has predominated in a prolonged period, affecting mainly agriculture, however to mitigate the effects PAIS technology was used as a significant alternative for small producers, mainly in offering benefits to the families that family farming, providing improvements in the quality of life.
\end{abstract}

Keywords: Nature; Economy; Sustainability.

\section{Introduction}

Aiming life to suit the field in the nature conditions derivations, man has created techniques and processes adapted to the environmental physical conditions in which lives giving it the name of social technologies that are low cost tools and can be used in any region, and it also has the community participation involved (FALCÃO SOBRINHO et al, 2015 and 2018; ALMEIDA et al, 2015; LIMA et al 2016).). Among these are the mechanized agriculture, irrigation techniques and use of heavy machinery. There are also techniques aimed at community participation, either planting in mandalas, agroecological backyards among others also called social Technologies.

As an example of community participation, the social technology referred to as Integrated and Sustainable Agroecological Production-PAIS, which is a model directed to small-scale farmers, aims at the sustainable production of organic foods, as well as the possibility of income from commercialization of diversified crops. The way of production is through the integration of animal production (birds) and vegetable (vegetables and fruits), in circular spaces to facilitate the supervision of the farmer and interaction of these activities. In addition, this is a new possibility of income in the family agriculture area and can be used by the farmer who wants to improve the conditions of production, enabling the cultivation of healthy food, ecosystems preservation, and natural resources appropriate management and development of diverse cultures that allow the residents to stay in their place. In addition, the programs sent to implement the technologies seek to empower farmers with technical guidelines. 
For its operation, the model has the following structure: central chicken coop, followed by three circles consisting of vegetables and fruits, in addition spatial capacity for the expansion of up to 10 flower beds at the maximum. In this way, the integration of concentrated animal and vegetable production in each plot helps to take advantage of the residues derived from these activities, facilitates the nutrients transportation through the same distance from the chicken coop to the circles and the better visualization of the area by the producer. However, if the area lacks natural protection, it should be protected against strong winds that may negatively affect the plantations. For this purpose, medium-sized trees must be planted to serve as windbreaks. It is also recommended that the land used for cultivation be flat, naturally lit, a source of water close to the water tank supply allowing the irrigation operation by gravity.

\section{Figure - 1 PAIS TECHNOLOGY (Illustration)}

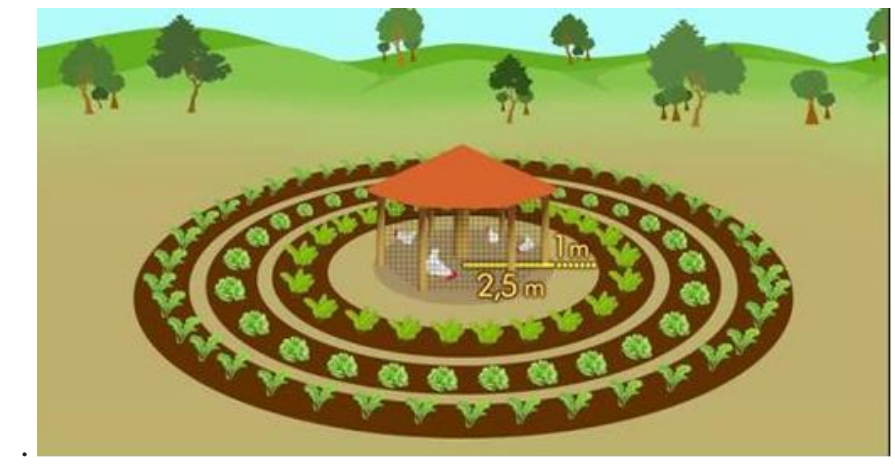

Source: Globo Rural's extracted image

Thus, we will treat in this research two communities with distinct locations: being in the community of Gregory, an environment of fluvial plain and Morgado an environment of transition, between backwoods and inselberg (Serrote do Madeiro). On this, Souza (2006) points out that smaller areas are smaller than the humid and subhumid ridges, dispersed by the backwoods depressions, derive from the work of differential erosion in sectors of very resistant rocks, with rocky reliefs, steep slopes and shallow soils.

In both communities, it can be seen that the relations of the natural and social elements influenced the behavior of the technologies and their mode of use. While it is evident the insertion of society in the context of the natural resources conducive to the deployment of technologies.

The reference of the essay is as follows from the bibliographical revisions to the foundations of the research, methodology, through the characterization of the areas under consideration, specifically the object of study, then the results and discussions reached, where they were explained and discussed with the illustrative aid of the photographic records acquired in field research and with the final considerations, it was concluded that the project presented is a technique of sustainable production and development carried out by rural families (farmers) engaged in a production based on the principles of agroecology. In this way, the relevance of this study is established, based on an integrated analysis of elements, based on the General Systems Theory approach, providing the elements involved with an understanding of the effectiveness of the analyzed social technology.

\section{Environmental characterization of the Study Area}

The study areas (Morgado and Gregorio) are located in the Municipality of Massapê, which are located in the northwestern portion of the state of Ceará between the geographical coordinates: Latitude (S) $3{ }^{\circ} 31$ '22 "and Longitude (W) $40^{\circ} 30$ '24. It is bordered to the north by the municipalities of Santana do Acaraú and Senador Sá, to the south, with municipalities Meruoca and Sobral, to the east with Santana do Acaraú and Sobral, and to the west with Senador Sá, Moraújo, Alcântaras and Meruoca (IPECE, 2017).

The Morgado area is located on the backland surface, which according to Falcão Sobrinho (2008), is a recessed area between the elevated environments, with an extension corresponding to $92 \%$ of the state of Ceará. The location of Gregório in the fluvial plains, in the middle course of the Acaraú River, is characterized according to Souza (2006), as flat areas resulting from fluvial accumulation subject to periodic flooding, are preferred areas for irrigation projects and also represent preferential sectors, most of the small-to-medium-sized coastal or backwoods cities. 


\section{Figure 2 - Community Location Map}

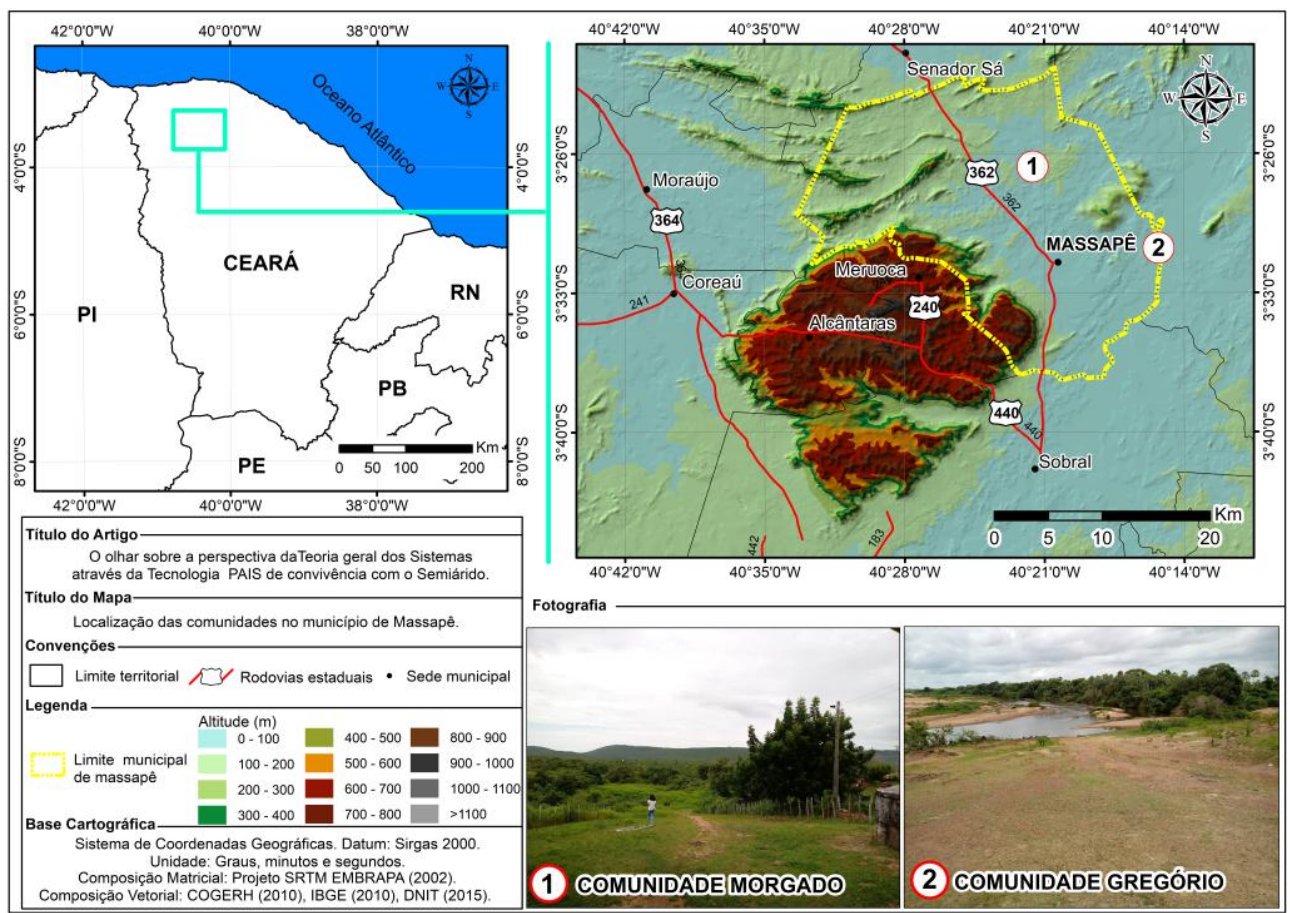

Source: Authors (2018)

In this way, the communities visited, although they differ by distance, and by the geomorphological characteristics, are located in semi-arid environment, this in turn constitutes a heterogeneous mosaic full of own characteristics and predominant in each space evidenced through the relief, climate, soil, hydrography and vegetation. Despite the natural elements great variability, there is something in common in the semi-arid environment. According to Ab'Sáber (2003) we have the importance of air masses EC (equatorial, continental) that due to the meteorological conditions of the Atlantic center west and the action of the trade winds, have low condition of penetrating the interplanaltic zones. Benefiting only the Wood Zone. These conditions influence the pluviometric irregularities with duration of six to seven months and prolonged period of drought (AB'SÁBER, 2003).

They are also areas susceptible to the consequences of soil erosion and degradation, by the removal of the vegetation cover by the traditional methods of use and cleaning of the area, through fires between the months of December and January leaving the soil naked and unprotected. (FALCÃO SOBRINHO, COSTA FALCÃO, 2006). The predominance of caatinga vegetation, due to its ability to adapt to the climate, fills almost the entire landscape, which is inserted in an intermittent drainage network, dividing spaces with communities dispersed mostly along streams such as waterworks water supply during drought periods. Currently the new practices of living with the semi-arid have allowed more autonomy in the water and food production acquisition impacting on life and local economy.

\section{Methodology}

The applied methodology was based on guided bibliographic reviews, beginning with the theoretical approach based on a systemic view of the study area. In this context, we report on the general theory of systems proposed by the theorist Bertalanffy around the 1930's. For the purposes of analysis we considered the nature, economy and sustainability of the environment (FALCAO SOBRINHO et al, 2017). In this sense, communities with natural diversity in the semi-arid region were favored for the study, in the case Morgado and Gregorio were allocated, due to the natural territorial characteristics that comprise the sertaneja surface and fluvial plain, which in turn, specify different conditions for geomorphological conditions. The survey conducted with the families was developed through on-site visits, and was based on an interview with the respective areas owners.

The objective expressed through the field practice was to obtain information regarding the: before and after the Technologies implementation, knowing about the main difficulties faced by the farmer to maintain the performance of this cultivation system, the way he deals with the land and the production, and which crops are developed as well as their economic directions. 
It should be added that the information referred to above does not constitute isolated responses, but it is fundamental that the information can be used to correlate them, in addition to supporting evolutionary considerations, for the improvement of the agricultural production system., natural physical issues. For temporary purposes, the families that were treated with the PAIS technology were visited 10 years ago.

\section{Results and Discussion}

The results obtained with the research showed that the communities presented the importance of the PAIS technology for living with the semi-arid region because it is a production system linked to sustainable management practices and also because it offers the possibility of income generation.

Before the PAIS implantation, Morgado and Gregorio predominated subsistence agriculture, combined with rudimentary techniques such as the use of fires, in the teachings of Costa Falcão (2006), the rudimentary techniques carried out in the months of December to January aggravate the erosive processes of the soils which are exposed to rainy periods. The beneficiaries of both communities pointed out that they had been contemplating the project for at least ten years and had only labor costs, but received all the equipment and technical training to handle the project.

Three projects were assigned to the Morgado and one to Gregorio. In the community of Morgado, during rainy periods, farmers had difficulties in maintaining the plantation beds intact due to the surface runoff of the water caused by the precipitation on a terrain with a steep slope. Two of the projects granted to the other families were deactivated due to this situation, so constant during this period that the farmer who resisted in remaining with the project was necessary to reinforce the beds with bricks to support the soil and the vegetables. During this season some vegetables did not develop because the soil was saturated, although in the dry season, the heat influenced negatively to the agricultural productivity, but it still presents greater development of the cultures, however the handling of this system requires greater care and dedication, in this season the farmers use coconut and carnauba straws to keep the soil moist for longer, mitigating the effects of evapotranspiration, due to the loss of soil moisture, this method also serves to reduce the time and frequency of irrigation, thus reducing the consumption of Water. In reference to the main crops produced by the community, there are some species of vegetables such as: coriander, onion, cherry tomatoes, maxixe, and in its surroundings there are fruit plantations, coconut, pomegranate, mango tomi.

These productions are focused on both consumption and marketing in agro-ecological fairs, encouraged by the rural workers' union of Massapê. Regarding the financial issue, in times of good production, the farmer reported that his profit had reached an environment of a minimum wage per month for the products sold at the fair, but today the technology produces around 50 products due to the scarcity of rainfall in the last years.

\section{Figure 3 - PAIS Technology in Morgado}

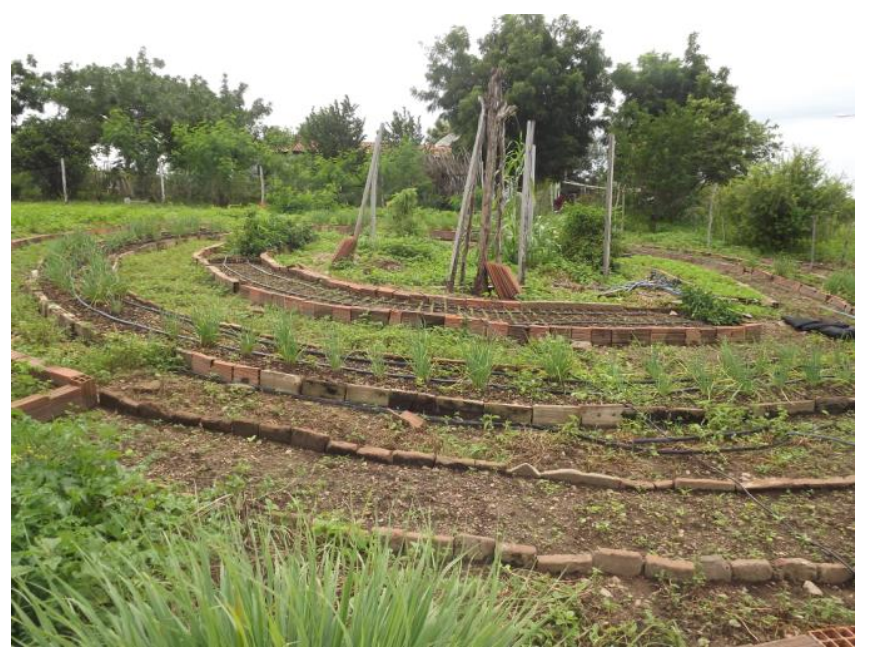

Source: Personal Archive

In relation to the community of Gregório, the PAIS technology is deactivated due to the difficulty of the farmers family in maintaining it in operation. It lay on flat ground, concerning the cultures developed in the community of Gregory, the presence of some plantations such as: coconut, graviola, ata, orange, banana, among others, after PAIS was deactivated in this area, only some vegetables continued to be cultivated. Unlike Morgado, in Gregorio the productions are not geared towards commercialization, only for own consumption. It is worth mentioning that organic production is still preserved in production. 


\section{Final Considerations}

The implementation of Integrated and Sustainable Agroecological Production (PAIS) technology is a positive and significant possibility for socioeconomic and environmental reasons. Considering that this, through the sustainable production of food, provides the production of food species beneficial to the livelihood of small families (farmers) who rely on family farming to provide income through the sale of remaining production. It is well known that social technology PAIS has contributed to the sustainable development, based on the use of small areas with different cultures, in an organic way, and the farmers have production for both survival and commercialization. That said, the implementation of the PAIS technology contemplates the quality of life of the farmers, even resulting in the development of standards directed to the environmental education of the people.

It is also worth noting that the integrated vision of nature, sustainability and economy are standards that can be achieved with viable social technologies for the well-being of nature and the community.

Acknowledgments: CNPq for the financial support through Edict 22/2014.

\section{References}

ALMEIDA, CARLIANA LIMA; FALCÃO SOBRINHO, JOSÉ. As cisternas de placas no cenário da paisagem de superfície sertaneja no semiárido cearense. Fórum Ambiental da Alta Paulista, v. 11, p. 188-205, 2015.

AB' SABER, A. N. Os domínios de Natureza no Brasil: potencialidades paisagísticas. São Paulo: Ateliê Editorial, 2003.

AB'SABER, A. Sertões e Sertanejos: uma geografia humana sofrida. Estudos Avançados. USP. São Paulo, 1999.

AB'SABER, A. Os Domínios Morfoclimáticos Semi- árido das Caatingas Brasileiras. Instituto de Geografia. USP. São Paulo, 1974.

ARAÚJO FILHO, J. A de. Contexto Geoambiental do Semi-árido do Ceará: Problemas e Perspectivas.em: FALCÃO SOBRINHO, J. e COSTA FALCÃO, Cleire Lima (orgs.) Semi-árido: diversidades, fragilidades e potencialidades. Sobral Gráfica, 2006.

BERTALANFFY, L. V. General Theory of Systems. New York, George Braziller. 1968.

COSTA FALCAO, C.L. Enclaves em meio ao semiárido nordestino: o maciço da Serra da Meruoca e o uso da terra. In: FALCAO SOBRINHO, J.; COSTA FALCAO, C.L.; SOUSA, R.N.R.; MOTA, F.A. Semiárido: diversidades naturais e culturais. IADE/UVA, Sobral, 2008.

FALCÃO SOBRINHO, JOSE; COSTA FALCÃO, C. L.; SILVA, E. V.; MENDES, M. V. R. Cearense Semi-Alarm Plate Tiles: The Case of IPU, Ceará, Brazil. Modern Environmental Science And Engineering, v. 4, p. 522$529,2018$.

FALCÃO SOBRINHO, JOSÉ; ARAÚJO, ANA PAULA MARQUES ; FALCÃO, ICARO LIMA COSTA ; FALCÃO, ÍTALO LIMA COSTA . Natureza, meio ambeinte e a teoria geral dos sistemas Bases Ambientais, Econômicas e Jurídicas. HOLOS (NATAL. ONLINE), v. 8, p. 104-125, 2017

FALCÃO SOBRINHO, JOSE; COSTA FALCÃO, C. L.; PAIVA, A. M.; MENDES, M. V. R. Implantação e uso de cisternas de placas no semiárido cearense: o caso de taperuaba, Sobral.. Revista Homem, Espaço e Tempo, v. 1, p. 37-50, 2015

FALCÃO SOBRINHO, J. FALCÃO C. L. C. de. Agricultura no Semi - Árido Cearense e Técnicas de Monitoramento de Processo Erosivo. in: FALCÃO SOBRINHO, J. e COSTA FALCÃO, Cleire Lima (orgs.) Semiárido: diversidades, fragilidades e potencialidades. Sobral Gráfica, 2006.

FALCÃO SOBRINHO, J; FALCÃO C. L. C. Práticas agrícolas inadequadas acentuam processo erosivo na Serra da Meruoca. R. Ci. e Téc., Fortaleza, ano 3, n. 3, dez./2001

FALCÃO SOBRINHO, J; COSTA FALCÃO, C.L. Geografia Física: a natureza na pesquisa e no ensino. Editora T.mais.oito. Rio de Janeiro, 2008.

FALCÃO SOBRINHO, J. A inserção antropogênica na construção e reorganização do cenário da paisagem do Vale do Acaraú, CE. Revista Brasileira de Geografia Física. UFPE, 2014.

IPECE, Instituto de Pesquisa e Estratégia Econômica do Ceará. Fortaleza. 2017.

LIMA, A. C. A.; FALCÃO SOBRINHO, JOSÉ . O estudo dos recursos hídricos no semiárido cearense. Revista Homem, Espaço e Tempo, v. 8, p. 88-105, 2016.

MINISTÉRIO DA SAÚDE. Pequenos cuidados: uma grande proteção. [2014]. Disponível em: <http://portalsaude.saude.gov.br/index.php/publicacoes-svs>. Acesso em: 20 dez. 2016.

SOUZA, M. J. N de. Contexto Geoambiental do Semi-árido do Ceará: Problemas e Perspectivas.em: FALCÃO SOBRINHO, J. e COSTA FALCÃO, Cleire Lima (orgs.) Semi-árido: diversidades, fragilidades e potencialidades. Sobral Gráfica, 2006. 